\title{
Psychosocial Distress in Breast Cancer Patients
}

\author{
$1^{\text {st }}$ Wenny Savitri \\ Nursing Department \\ Universitas Jenderal Achmad Yani \\ Yogyakarta \\ Yogyakarta, Indonesia \\ wenny.savitri1@gmail.com
}

\author{
$2^{\text {nd }}$ Amin Haryati \\ Nursing Department \\ Universitas Jenderal Achmad Yani \\ Yogyakarto \\ Yogyakarta, Indonesia \\ aminharyati@gmail.com
}

\begin{abstract}
Background: Cancer is one of the leading causes of cancer deaths in Indonesia. Breast cancer and its therapy cause several impacts on patients, including physical, psychological, and social. Little information has been gathered regarding non-physical impacts on patients with breast cancer in the form of psychosocial distress. In contrast, this information is significant to provide better management of cancer patients. Objective: To identify the psychosocial distress of breast cancer patients. Methods: A descriptive quantitative study using Psychosocial Distress Questionnaire-Breast Cancer was applied to 24 breast cancer patients admitted in Panembahan Senopati Bantul of Yogyakarta General Hospital. The data were then analyzed by using univariate analysis. Results: All of the respondents were women aged 26-65 years old. Most of them rarely experienced psychosocial distress $(83.3 \%)$. The study revealed that from 9 subscales of psychosocial distress, most of the respondents rarely experienced trait anxiety $(66.7 \%)$; rarely obtained social support $(83.3 \%)$; faced social problem $(62.5 \%)$, physical problem $(62.5 \%)$, and depressive symptoms $(62.5 \%)$. Majority of the women were also rarely having body image problem $(45.8 \%)$ and state anxiety $(83 \%)$; never had a sexual problem $(50 \%)$, but most of them equally stated experienced a financial problem at the same amount of "rarely" and "often" choices (33.3\% for each). Conclusion: Psychosocial distress in patients with breast cancer in Panembahan Senopati Bantul of Yogyakarta General Hospital is rarely experienced.
\end{abstract}

Keywords- breast cancer, psychosocial distress, psychosocial distress questionnaire-breast cancer

\section{INTRODUCTION}

Breast cancer is one of the leading cancer problems diagnosed in Indonesia, which counted around $16.7 \%$ of cancer patients all ages [1]. In contrast, Yogyakarta is the most prevalent province of breast cancer diagnosis amongst other areas in Indonesia [2]. Management of breast cancer patients is a combination of several therapies consisting of multiple sequences for the long-term. These therapies will affect patients physically and psychosocially [3]. Most physical effects of complaints by patients are changes in skin color, pain, and dizziness [4]. Psychological effects include body image disturbance, anxiety, insomnia, rejection, depression, loss of living faith, or hopeless [5]. Social effects are feeling ashamed and self-isolation. These impacts are all negatively associated with quality of life of breast cancer patients [4]. Therefore, nurses need to identify the psychosocial distress of breast cancer patients as part of a nursing assessment to manage breast cancer patients better. Very little information regarding psychosocial distress exists to use in the nursing area. This research is a pilot study made for a glance at the information in nursing research.

\section{METHOD}

A quantitative, non-experimental study was applied to 24 breast cancer patients admitted in Panembahan Senopati Bantul General Hospital of Yogyakarta. The sample was recruited by using convenience sampling during their stay in the hospital. Instruments used in the study consist of the demographic questionnaire made by researchers and Psychosocial Distress Questionnaire - Breast Cancer (PDQBC) [6], which was translated from Dutch to Bahasa Indonesia using back-translation technique. The questionnaire consists of 35 items of 9 subscales: trait anxiety, state anxiety, depressive symptoms, body image, financial problem, sexual problem, physical problem, social support, and social problem in cancer patients. The data were then analyzed using descriptive analysis.

\section{RESULT}

Table 1 shows the demographic characteristic of the respondents. Based on table 1 , all of the respondents were female aged 16 - 65 years old; the majority were married $(87.5 \%)$ with children $(95.8 \%)$; occupied $(50 \%)$ but with low income $(91.7 \%)$. Most of them were diagnosed with stadium IIA/B Breast Cancer (54.2\%) for more than 2 to 5 years ago, received a combination of surgery and chemotherapy $(87.5 \%)$, and all of them were covered with health care insurance. 
Table 1. Demographic Characteristic of Breast Cancer Patients $(\mathbf{N}=\mathbf{2 4})$

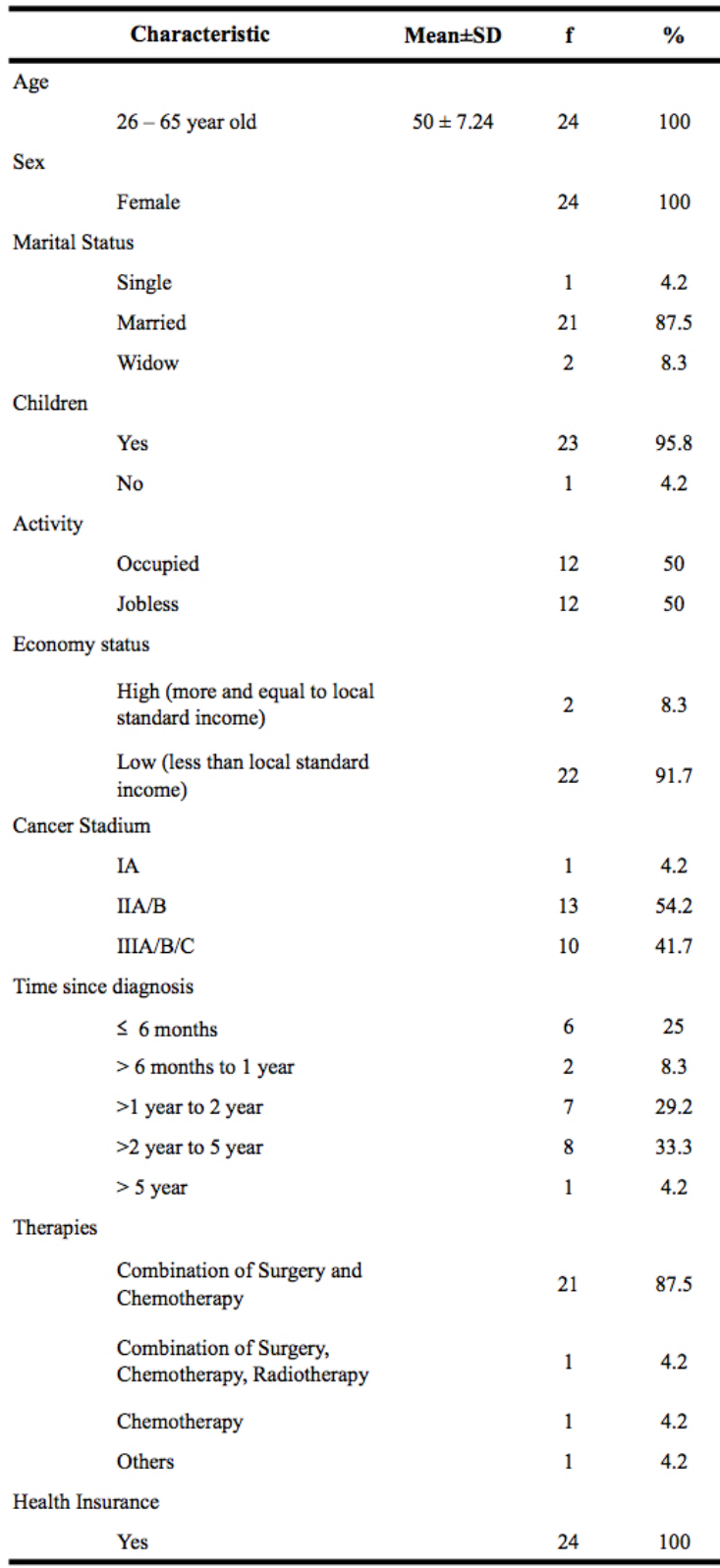

Table 2. Description of Psychosocial Distress

\begin{tabular}{lcccccccc}
\hline \multicolumn{1}{c}{ Psychosocial Distress } \\
\hline \multirow{2}{*}{ Subscale } & \multicolumn{2}{c}{ Never } & \multicolumn{2}{c}{ Rarely } & \multicolumn{2}{c}{ Often } & Frequent \\
\cline { 2 - 10 } & f & $\%$ & f & $\%$ & f & $\%$ & f & $\%$ \\
\hline Trait Anxiety & 4 & 16.7 & 16 & 66.7 & 4 & 16.7 & 0 & 0 \\
Social Support & 1 & 4.2 & 20 & 83.3 & 3 & 12.5 & 0 & 0 \\
Social Problem & 6 & 25.0 & 15 & 62.5 & 2 & 8.3 & 1 & 4.2 \\
Physical Problem & 1 & 4.2 & 15 & 62.5 & 8 & 33.3 & 0 & 0 \\
Depressive symptoms & 7 & 29.2 & 15 & 62.5 & 2 & 8.3 & 0 & 0 \\
Body Image & 3 & 12.5 & 11 & 45.8 & 8 & 33.3 & 2 & 8.3 \\
Sexual Problem & 12 & 50.0 & 7 & 29.2 & 4 & 16.7 & 1 & 4.2 \\
Financial Problem & 6 & 25.0 & 8 & 33.3 & 8 & 33.3 & 2 & 8.3 \\
State Anxiety & 1 & 4.2 & 20 & 83.3 & 3 & 12.5 & 0 & 0 \\
\hline
\end{tabular}

Table 2 depicted description of the psychological distress of breast cancer patients where the majority of the patients rarely experienced trait anxiety $(66.7 \%)$; rarely obtained social support $(83.3 \%)$; faced social problem $(62.5 \%)$, physical problem (62.5\%), and depressive symptoms $(62.5 \%)$. Majority of the women were also rarely having body image problem $(45.8 \%)$ and state anxiety $(83 \%)$; never had a sexual problem (50\%), but most of them equally stated experienced a financial problem at the same amount of "rarely" and "often" choices (33.3\% for each).

These findings, in general, showed a positive state of psychosocial distress of women with breast cancer in Panembahan Senopati Bantul General Hospital of Yogyakarta. Older age is believed to contribute to less risk of psychological distress in women with breast cancer, while younger women who have not already had their children, the diagnosis of breast cancer means a threat of death [7]. The mean age of women in the study was $50 \pm 7.24$, which is included in middle-aged adults, and most of them were also married $(87.5 \%)$ and had children $(95.8 \%)$.

Chemotherapy, endocrine therapy, surgery, and radiation can significantly alter a woman's sexual health and function. Most women in this study received a combination of surgery and chemotherapy. Women treated with mastectomy reported more disruption in their lives and significantly lower scores in body image, role, and sexual domains [8]; as we can see, $33.3 \%$ of the women reported often experienced distress regarding their physical and body image changes.

Different findings found in this study where the majority of the respondents $(50 \%)$ stated never had a sexual problem. Indonesia is a country with a culture of patriarchy, including control of patriarchy on female sexuality. This culture makes women are no longer have authority over their bodies. When there is any problem affecting the female body (biological), it happens because of women's faults [9]. Thus this may contribute to less problem for the respondents in terms of sexual needs.

Social support for women with breast cancer consists of instrumental support and emotional support [7]. The support may come from their close ones. They can be a spouse or other family members. The women in this study rarely experienced distress from social support (83.3\%). Data from table 1 showed that most of the women were married (87.5) and had children $(95.8 \%)$, which can be their source of social support that explains the positive result of psychological distress.

Even though all respondents were covered by health insurance, $33.3 \%$ of the women still described often had financial problems. The data showed that $50 \%$ of respondents were occupied, which means that during their treatment in the hospital, they could not work and earning money for the long term, which also affected their income. This finding is following previous studies showing that the most unmet psychosocial needs among cancer patients were 'help with financial matters', which was related to low income [10].

\section{CONCLUSION}

In general, psychosocial distress in patients with breast cancer in Panembahan Senopati Bantul of Yogyakarta General Hospital is rarely experienced. However, physical, 
body image and financial problems need to be highlighted in nursing management for breast cancer patients as patients often experience those subscales.

\section{REFERENCES}

[1] Population Fact Sheets : Indonesia: International Agency for Research on Cnacer; 2018 [cited 2020 July 9th]. Available from: https://gco.iarc.fr/today/data/factsheets/populations/360-indonesiafact-sheets.pdf.J. Clerk Maxwell, A Treatise on Electricity and Magnetism, 3rd ed., vol. 2. Oxford: Clarendon, 1892, pp.68-73.

[2] Laporan Nasional Riskesdas 2018. Kementrian Kesehatan Republik Indonesia, 2018.

[3] van Leeuwen M, Husson O, Alberti P, Arraras JI, Chinot OL, Costantini A, Darlington AS, Dirven L, Eichler M, Hammerlid EB, Holzner B, Johnson CD, Kontogianni M, Kjær TK, Morag O, Nolte S, Nordin A, Pace A, Pinto M, Polz K, Ramage J, Reijneveld JC, Serpentini S, Tomaszewski KA, Vassiliou V, Verdonck-de Leeuw IM, Vistad I, Young TE, Aaronson NK, van de Poll-Franse LV; EORTC QLG. Understanding the quality of life (QOL) issues in survivors of cancer: towards the development of an EORTC QOL cancer survivorship questionnaire. Health Qual Life Outcomes. 2018 Jun 4;16(1):114. R. Nicole, "Title of paper with only first word capitalized," J. Name Stand. Abbrev., in press.
[4] Irawan E, Rahayuwati L, Yani DI. Hubungan Penggunaan Terapi Modern dan Komplementer terhadap Kualitas Hidup Pasien Kanker Payudara. Jurnal Keperawatan Padjadjaran. 2017;5(1):19 - 28.M. Young, The Technical Writer's Handbook. Mill Valley, CA: University Science, 1989.

[5] Pristiwati AD, Aniroh U, Wakhid A. Hubungan Dukungan Keluarga dengan Respon Psikologis Pasien Kanker Payudara yang Menjalani Kemoterapi di Poliklinik Onkologi RSUD Kabupaten Temanggung. Indonesian Journal of Nursing Research. 2018;1(1):1 - 9.

[6] Bogaarts MPJ, Oudsten BLD, Roukema JA, Riel JMGHV, Beerepoot LV, Vries JD. Development of the Psychosocial Distress Questionnaire-Breast Cancer (PDQ-BC): a breast cancer-specific screening instrument for psychosocial problems. Support Care Cancer. 2010;19(10):1485 - 93.

[7] Hewitt M, Herdman R, Holland J, editors. Meeting Psychosocial Needs of Women with Breast Cancer. Washington, D.C.: The National Academies Press; 2004.

[8] Boswell EN, Dizon DS. Breast Cancer and Sexual Function. Translational Andrology and Urology. 2015;4(2):160 - 8 .

[9] Fujiati D. Seksualitas Perempuan dalam Budaya Patriarkhi. Muwazah. 2016;8(1):26 - 47.

[10] Fitri SUR, Maneewat K, Sangchan H. Psychosocial Needs among Indonesian Women Diagnosed with Breast Cancer. Journal of Nursing and Health Care. 2017;4(2):67 - 72. 